
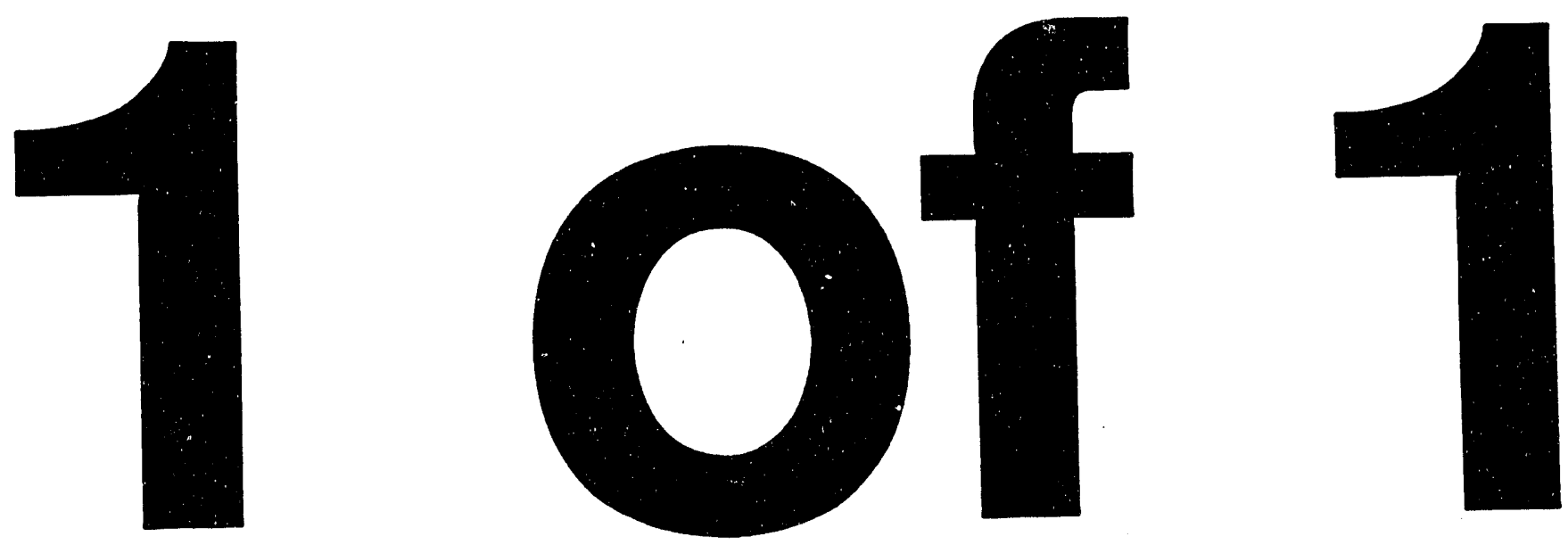
UCRL-JC-115809

PREPRINT

\title{
Pollution Prevention: Avoiding the Need to Manage Wastes
}

\author{
Michael Meltzer
}

This paper was prepared for submittal to the

IspraEurocourse Joint Research Center

September 13-17, 1993

Ispra, Italy

December 1993

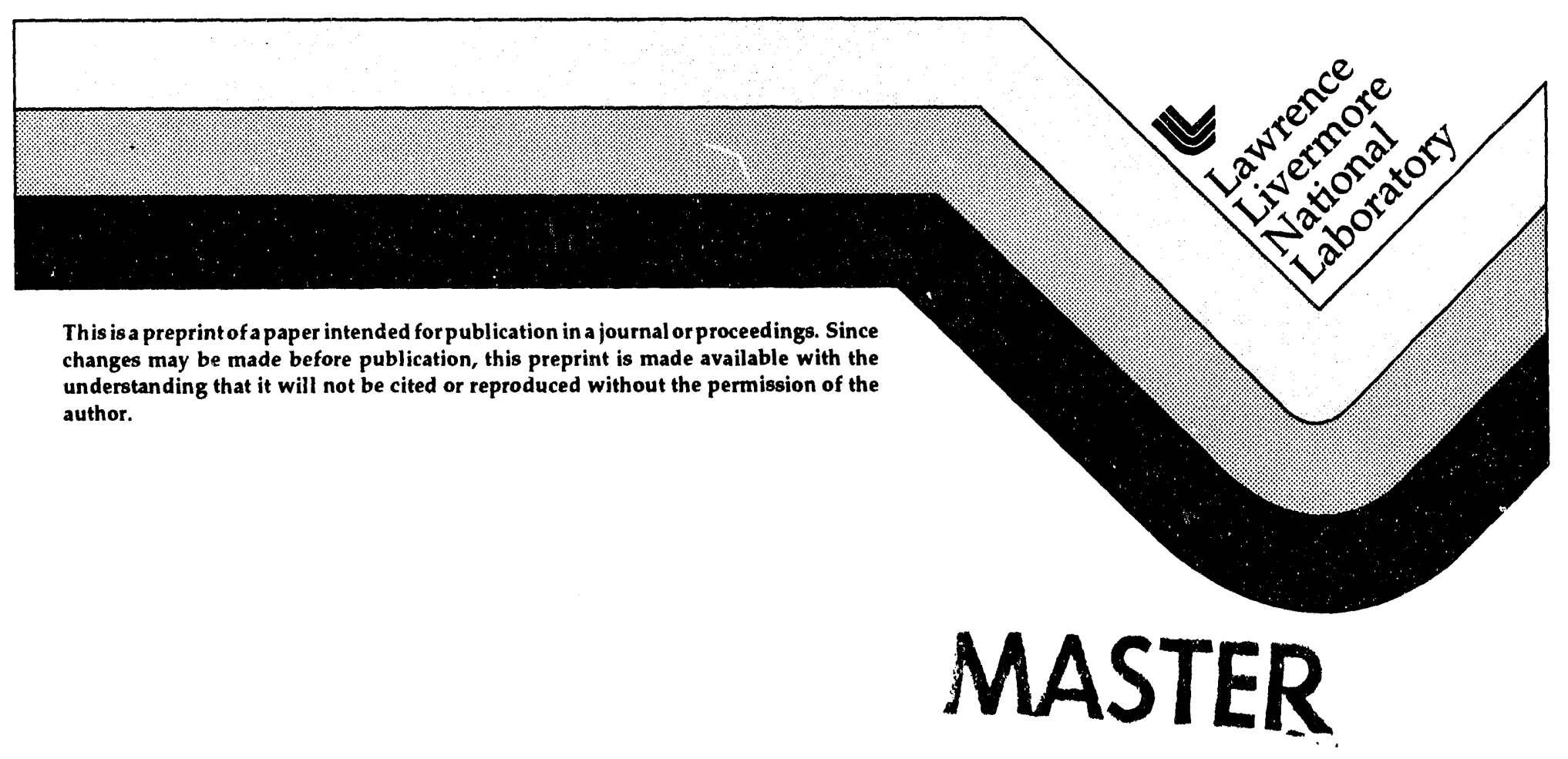




\section{DISCLAIMER}

This document was prepared as an account of work sponsored by an agency of the United States Government. Neither the United States Government nor the University of California nor any of their employees, makes any warranty, express or implied, or assumes any legal liability or responsibility for the accuracy, completeness, or usefulness of any information, apparatus, product, or process disclosed, or represents that its use would not infringe privately owned rights. Reference herein to any specific commercial products, process, or service by trade name, trademark, manufacturer, or otherwise, does not necessarily constitute or imply its endorsement, recommendation, or favoring by the United States Government or the University of California. The views and opinions of authors expressed herein do not necessarily state or reflect those of the United States Government or the University of California, and shall not be used for advertising or product endorsement purposes. 


\title{
POLLUTION PREVENTION: AVOIDING THE NEED TO MANAGE WASTES
}

\author{
Michael Meltzer \\ Lawrence Livermore National Laboratory \\ Environmental Protection Department P.O. Box 808 \\ Livermore, California 94550 \\ U.S.A.
}

\section{Introduction}

Today's industrial processes generate many types of waste products that constitute risks to human health and the surrounding environment. While proper waste management procedures can lower this risk, prevention of the waste's generation will eliminate the risk. For this reason, the United States has established pollution prevention as a national objective, through the passage of its Pollution Prevention Act of 1990.

Pollution prevention involves a wide range of approaches, all with the same objective: to reduce or eliminate the creation of waste at its source; in other words, within the process that generates it. This objective, so beneficial to the environment, also coincides with industrial economic interests. Pollution prevention measures and greater process efficiency go hand in hand, and typically result in lower operating costs as well as greatly reduced waste management expenses.

The U.S. Environmental Protection Agency defines pollution prevention as the maximum feasible reduction of all wastes generated at production sites. This objective is accomplished largely through source reduction and reuse of input materials during production.

\section{Source Reduction}

Source reduction involves a focus on the mechanisms of waste generation within an industrial process, and the altering of those mechanisms in such a way as to prevent the creation of wastes to the maximum extent feasible. The specific goals of a source reduction methodology are to reduce the volume of waste generated, its toxicity, or both.

Two typical source reduction approaches are product changes and process changes. Product changes involve alterations in the composition or use of intermediate or end products. Such changes reduce waste from manufacturing operations, or from use or disposal of the products. Eliminating chromed pieces of trim from an automobile's design eliminates a source of hazardous metal wastes during the manufacturing process. Redesigning an aerosol can so that it doesn't use a propellant that is an ozone depleter or flammable reduces problematic air emissions both during use and disposal of the can. 
Precess changes focus on how the product is made. Developing parts cleaning methods that employ detergents and water instead of chlorinated solvents prevents toxic air emissions and the generation of problematic liquid wastes. Draining a metal part over its plating bath for extended times so as to reduce "dragout" of plating chemicals cuts down on the volume of hazardous substances in the rinse baths following plating. It also uses the materials more efficiently, lowering production costs.

Other process changes are listed in Table 1.

\section{Reuse of Input Materials During Production}

Reuse of materials during production may involve in-process solvent recycling units, recovery of metals from spent plating baths, or recovery of acids, caustics or cleaning solutions from spent process baths. This approach views the chemicals left over after production as resources, not wastes, for which beneficial uses must be found whenever feasible.

While off-site recycling (for instance, recovery of metals or solvents at centralized facilities away from the production plant) can be environmentally beneficial, and helps to preserve raw materials and reduce the amount requiring disposal, it does create pollution during transport as well as in the reclamation process. Reuse of materials at the production site typically generates less waste and presents less risk of worker exposures and environmental releases. For these reasons, off-site recycling does not come under the EPA's definition of pollution prevention (EPA 1992).

Waste treatment, concentration of hazardous wastes to reduce volume, and dilution of liquid wastes to avoid regulatory requirements for treatment are also not considered pollution prevention, nor is the transfer of a hazardous material from one medium to another (i.e., allowing a solvent to evaporate so as to eliminate a liquid hazardous waste).

There are certainly times when treatment and other approaches such as media transfer are the most appropriate solution to a waste problem. For instance, using activated carbon to remove solvents from wastewater can be very beneficial, even though in regenerating the carbon, the soivents it has picked up may be released to the atmosphere. But while there are times when management of wastes is appropriate, generally prevention of wastes is better. As illustrated below, pollution prevention can lower environmental risk while at the same time increase a plant's profits.

\section{Increased Profitability Through Pollution Prevention: Two Electroplating Examples}

\subsection{PLATER A: IN-PROCESS RECYCLING AND INPUT MATERIAL CONTROL}

Plater A specializes in decorative chrome plating. Because of the short dwell times and frequent changes of parts from one bath to another, there is typically a large amount of dragout of chemicals from the baths. The high viscosity of the hexavalent chromium baths adds to this dragout, for the solution drains slowly from the parts. 
Traditionally, dragout on the parts was removed in flowing rinse baths that carried the hexavalent chromium and other chemicals down the drain into the shop's hazardous waste treatment system. Typically $25 \%$ of the plating chemicals went down the drain instead of being plated onto the parts. This loss used to be common in American chrome plating shops and in many locales still is. It is a process that is both inefficient from a production point of view, as well as one that generates large amounts of highly toxic waste.

In chrome plating as well as in many other types of metal finishing, the amount of waste generated far exceeds the amount of hazardous material first added. For instance, Plater A, a small to medium-sized shop, used to input an average of 600 to 800 pounds of chromic acid flake per month. To treat the waste solutions containing this chromium, 1000 to 2000 pounds of sodium metabisulfate were required to reduce the hexavalent chrome to a trivalent state, after which 3000 to 5000 pounds of liquid caustic soda was required. This resulted in 20 yards of filter cake (Foss 1989).

With increased costs of waste management and disposal, incentives were created to prevent such a large generation of waste from the plating process. If the chromic acid used to rinse off the parts could in some way be diverted and recovered rather than going down the drain, it would greatly reduce the rapidly growing treatment and disposal expenses, as well as cut down on input material requirements. To accomplish this, Plater A designed a closed-loop recycling system in which chrome-bearing rinse water was fed back into the process baths instead of allowed to flow down the drain.

The problem Plater A was confronted with was this: If the dilute rinse water stream were fed directly back into the plating bath, it would dilute the metal concentration of those baths and eventually cause them to overflow. Because of the low operating temperature of the plating bath (105 degrees $F$ ), its evaporation rate would be far less than the flow of rinse water back into it.

To surmount this problem, the chrome-bearing rinse waters are first evaporated and concentrated and then fed back into the process bath. A low-cost atmospheric evaporator is used to provide an evaporation rate of 15 gallons per hour and is run for 16 hours per day. Automatic liquid-level sensors on the plating bath control rinse water flows back into it whenever solution levels drop.

Once this system was installed, a need was created to pay strict attention to what went into the plating tank and rinse baths. When rinse waters had been run down the drain, impurities in the system were rapidly flushed out. But with a closed-loop system, where rinse waters are fed back into the process, contaminants can quickly accumulate. Because of this, measures had to be taken to prevent nickel coming from an upstream bath from entering the chrome tank, for it would shorten the bath's usable life. This is accomplished through better rinsing of parts between the nickel and chrome baths. General controls on impurities entering the system have been implemented as well. Demineraiized water is required. Chloride buildup has to be prevented.

The closed-loop recovery system has worked well for several years. It saved the shop $\$ 2000$ to $\$ 3000$ per month, or $\$ 24,000$ to $\$ 36,000$ per year. Chrome consumption dropped from 600 to 800 pounds per months to 100 pounds, sodium bisulfate requirements dropped from 2000 to 300 pounds monthly, and there were proportionate reductions in filter cake generation. Furthermore, better control of the plating process and more consistent quality in the product was achieved. 


\subsection{PLATER B: SOURCE REDUCTION THROUGH INPUT MATERIAL CHANGES}

Converting a production process to use of different input chemicals can change a production line with a high degree of environmental risk into one that is much safer, as well as more efficient. Like Plater A, Plater B runs a decorative chrome plating shop. The shop converted an automated hexavalent chrome line to a trivalent chrome system, at a cost of $\$ 70,000$. While the shop owners were not adverse to the environmental benefits of this, their main reason for conversion was the increased production rate that they could achieve with a trivalent line.

Although hexavalent processes have been used for electroplating for 70 years, they have serious environmental as well as performance problems associated with them. Hexavalent chromium is a highly toxic material and a suspected carcinogen. Its use poses a danger to human health, particularly shop personnel, as well as to the environment (Snyder 1989). Hexavalent chromium can escape the plating line through spills, leaks, in rinses and discarded baths, and in hydrogen bubbles formed during plating operations (DHS 1989).

There are also performance deficiencies associated with hexavalent chromium use that result in many reject parts and other problems that cost a shop owner money. These deficiencies include:

- Poor covering power (especially around holes and slots)

- Burning

- White-washing

- Sensitivity to ripples in power supply

- Low-energy efficiency. Ninety percent of the electric power applied goes into generation of hydrogen.

As mentioned in the previous section, a number of chemicals are required to treat hexavalent chromium wastes, which must be reduced to trivalent chromium during the process. Because of the high chrome concentration in hexavalent baths, as well as the reduction step required, hexavalent chromium operations result in large volumes of hazardous sludge generated.

4.2.1 Advantages Offered by Trivalent Chromium Systems: Trivalent systems suitable for decorative chrome plating applications can reduce an electroplating shop's expenses in a number of ways:

1. Lower Metal Concentrations: Chromium concentrations in trivalent plating baths are typically less than 1 ounce per gallon (oz/gal) (Gumm 1989). It is a much more efficient plating system than hexavalent baths in which chromium concentrations of 15 to $40 \mathrm{oz} / \mathrm{gal}$ are required to produce a very similar plate. Lower heavy metal concentrations mean less waste treatment costs and less hazardous sludge generated in trivalent systems. Reducing sludge quantities also saves money in haulage and disposal fees.

2. No Reduction Step: By installing a trivalent system, the need to reduce hexavalent chrome wastes to their trivalent state can be avoided (Robison 1978). Since three pounds of sodium metabisulfite are required to reduce each pound of chromic acid, significant quantities of chemicals, as well 
as equipment and labor costs, are eliminated by switching to a trivalent system.

3. Rack Populations Can Be Increased: Trivalent chromium chemicals produce a high-quality plate even when rack densities are increased $15 \%$ to $25 \%$ above those for hexavalent chrome systems. Thus, production rates can be significantly increased.

4. Fewer Rejects: The throwing power of trivalent chromium is excellent. It is difficult to burn parts, too, even with current densities above 100 amp/ $\mathrm{ft}^{2}$ Trivalent systems do not experience the white-washing problems that hexavalent systems do.

5. Reduced Dragout: Trivalent chromium baths are less viscous than hexavalent ones. Less solution clings to the parts that are withdrawn from the bath. Thus, less hazardous material gets into the rinse water. This reduces both treatment expenses and material costs for the makeup chemicals.

6. No Mist: The eye-stinging, throat-irritating mist that is emitted from a chromic acid bath is almost completely absent in a trivalent system. The hexavalent chromium entrained in that mist is a suspected carcinogen. Besides being unpleasant to breathe, fumes from a hexavalent system present a danger to personnel and to the environment surrounding the shop.

7. Reduced Liability: Use of hexavalent chromium constitutes a liability to the shop due to the dangerous nature of the chemical. Spills and other accidental releases of hazardous wastes can lead to lawsuits that might have been avoided if safer chemicals were used.

4.2.2 Barriers to Trivalent Chromium Use: While trivalent chromium systems offer some distinct advantages over hexavalent chromium, there are potential problems associated with their use. In the past, color was a big problem. The plate was darker and not as shiny. This problem has been greatly reduced (Durney 1986). The trivalent system developed by Canning Materials (Smart 1983) produces plates that are as shiny and of as high a quality has hexavalent chromium plates. If the trivalent chromium parts are placed side by side with hexavalent chromium parts, however, there is a noticeable color difference. This can be a problem in mixed batches of parts that have been plated using the two different methods.

The plating line that was converted uses a 3000 gallon chromium bath, preceded by a nickel bath. The production rate is 75 racks per hour, and with the old hexavalent system, $12 \mathrm{ft}^{2}$ of parts could be stacked on each rack.

Plater B stacked $15 \%$ to $20 \%$ more surface area of parts on each rack in the new trivalent system. The additional production rate increased profits by $\$ 204$ per shift. It is the nickel plating bath that precedes the chromium bath, however, that limits the number of parts per rack and prevents Plater A from adding even more parts. When the parts density is too high, nickel plates poorly in the recesses and crevices of the parts: A good chrome plate cannot be achieved unless there is a good nickel plate underneath it.

Plater A increased rack densities by closely controlling nickel concentrations in the plating bath. By keeping concentrations at $8 \mathrm{oz} / \mathrm{gal}$, greater parts densities on the racks 
were achievable. Nickel densities often got up to 10 to $14 \mathrm{oz} / \mathrm{gal}$, due to a closed loop recovery system that recycles nickel from the rinse tanks.

The reject rate for poorly plated parts for the hexavalent system previously used was $1.5 \%$ of all parts, while for the trivalent system, it is only $0.5 \%$, and possibly lower. This means that with the new trivalent system, almost one more rack of good parts is produced every hour. In terms of dollars, an additional \$54 of profit per 8-hour shift is realized because of avoided rerun costs due to the lower reject rate.

Because trivalent system waste streams do not need to go through a reduction step, no sodium metabisulfite or lime is needed. This saves the shop $\$ 31$ per shift.

The biggest disadvantage of the trivalent system is that the plating chemicals are considerably more expensive. Before the new system was installed, it was estimated by the supplier that trivalent chemicals would cost $\$ 70$ more per 8 -hour shift than hexavalent chemicals. In actuality, the cost for the trivalent chemicals is $\$ 113$ more per shift. More chemicals have had to be used than originally estimated in order to obtain a high-quality plate.

A detailed comparison of the cost of the two systems is given in Table 2. Notice that the trivalent system generates $\$ 182$ greater profits per shift. The shop runs two shifts, five days per week. Thus, the trivalent system produces an additional $\$ 95,000$ profit annually.

Physical characteristics of the trivalent system are summarized in Table 3.

Waste disposal costs for the two systems were not available since wastes from the chrome line were mixed with those from a much larger zinc line. Because far less sludge is generated with a trivalent system, the actual cost savings is expected to be considerably higher than reported.

\section{Reducing Waste Management Costs Through On-Site Reuse: A Study of a Brass Foundry}

Plant $\mathrm{X}$ is a foundry manufacturing cast brass plumbing fixtures. The plant uses an alloy consisting of 79\% copper, $12 \%$ zinc, $7 \%$ lead, and $2 \%$ tin to produce 10 to 12 million $\mathrm{lb} / \mathrm{yr}$ of brass plumbing fixtures. Hazardous waste streams generated in the process include raw slag from the induction furnaces, foundry sands from molds, wastecasting metal, metallic floor sweepings, metal-rich furnace fumes collected in baghouses, nonfurnace baghouse wastes, and airborne dust from molding operations.

Increasing waste disposal costs have made each of these streams expensive to manage, creating a strong incentive to prevent their generation. For instance, the plant used to generate 3000 tons per year of sand wastes. Recent changes in land disposal restrictions require metal fixation before disposal. The total cost was raised to $\$ 300$ per ton, or $\$ 900,000$ per year.

To reduce high waste management costs, Plant $\mathrm{X}$ has implemented a number of different pollution prevention approaches for the various streams. The common theme running through most of Plant X's pollution prevention approaches is to view the waste streams as resources that can be either (1) fed back into the manufacturing process, thus cutting down on input materials and avoiding waste management expenses; or (2) converted into a new, salable product. The approaches for the different waste streams are described below (DHS 1990). 


\subsection{RAW SLAG: USABLE METAL EXTRACTION}

Raw slag from the furnace is hazardous due to the metals it contains. It is solidified then sent to a ball mill for crushing. After this, it is sent through a series of finer and finer screens, each of which removes different metal wastes. The larger chunks are sent directly back into the casting process, first being remelted in the furnaces. Metal fines picked up by 40 mesh ( 40 wires per inch) screens are more difficult to recycle because oxide layers cause them to float on molten slag in the furnace, and not remelt. They are sent offsite to a reclaiming facility. "Slag dust" that passes the $\mathbf{4 0}$ mesh screen also contains considerable metal; this is extracted at an offsite smelter, and brought back to the foundry to be reused.

Figure 1 depicts the recycling and reuse paths of the raw slag and other waste streams generated by the foundry's operations.

\subsection{FOUNDRY SAND: METAL EXTRACTION AND MATERIAL CONVERSION}

Spent foundry sands from molding operations are initially passed through a series of screens, separating the fine sands that are reused in molds. The oversized stream that does not pass the screens is termed "raw core butt" and consists of chunks and grains of coarse sand, as well as metal. Vibrating screens and a ball mill are used to further separate the components of this stream and to crush the oversized chunks of sand. Through use of a magnetic separator, the metal in the stream is separated into ferrous and nonferrous streams. The ferrous is sent to an offsite metal reclaimer, while the nonferrous component is remelted in the foundry's furnaces. This process is detailed in Figure 1.

Undersized "dust" that is not suitable for reuse in the molds was until recently divided into hazardous and nonhazardous streams, according to metal content. Of the 3000 tons generated, 1000 was categorized as hazardous and disposed of at a cost of $\$ 200$ per ton, or $\$ 200,000$ per year. The 2000 tons of nonhazardous sand dust was disposed of in a sanitary landfill at a cost of $\$ 50$ per ton, or $\$ 100,000$ per year. These costs covered transportation disposal and taxes.

When land disposal regulations became more strict and the "land ban" took effect, the waste management cost of these streams skyrocketed. The entire 3000 tons of the stream had to be considered hazardous, and required fixation of the metal content before land disposal. As mentioned above, this brought the cost of waste management to $\$ 300$ per ton, or $\$ 900,000$ annually.

This was far too high a cost for Plant $\mathrm{X}$ to absorb. After considerable research and planning, the plant developed a multifaceted approach that eliminated the dust as a waste stream, recycling it in-house or converting it into a salable product. The first step was to install a 1700 degree $F$ thermo-calcining furnace to burn all organic contaminants off of the dust. After the furnace, the sand dust is transferred to a pneumatic scrubber that uses high velocity air to smash the sand against a plate. This operation helps to separate the fines that cannot be recycled from the reusable portion. The separation is completed in a cyclone scrubber. Using this approach, $80 \%$ of the stream is reclaimed and reused in moldmaking. The 600 tons of fines, consisting of shattered sand and clay particles, are detoxified using a new thermal fixation process.

The fixation process, developed by Ceramic Bonding Inc. uses alumina-silicate clays and a 2000 degree $\mathrm{F}$ firing temperature to produce a ceramic material. The metal 
contaminants in the waste stream are physically and chemically bonded to the aluminasilicate matrix, resulting in a material that is extremely resistant to acid leaching, even under extreme $\mathrm{pH}$ conditions. Furthermore, the metal bonded into the ceramic adds to its strength, making it an excellent construction aggregate. Plant $\mathrm{X}$ is planning on marketing the material for use in light-weight cinder block fabrication.

\subsection{WASTE CASTING METAL}

More than $50 \%$ of the metal poured into a mold is not a useful part of the casting itself. For example, the channel formed in the sand mold to allow metal to enter the mold will itself fill up with metal during the casting process. This excess metal is separated from the cooled casting and remelted.

Castings themselves are blasted with steel shot to clean their surfaces, and then inspected. Although most metal in a reject can be remelted, some metal and sand finds its way into foundry sand waste streams. Good castings go through cutting and grinding operations that remove more recyclable metal.

\subsection{FLOOR SWEEPINGS}

Metallic floor sweepings are remelted in the furnaces.

\subsection{FURNACE FUMES}

Baghouses collect fumes rich in zinc oxide from the furnaces. The baghouse dust is sold to a fertilizer manufacturer who reacts the zinc fraction with sulfuric acid to produce zinc sulfate. This is used as an additive for almond tree fertilizer.

\subsection{NONFURNACE BAGHOUSE WASTES}

Airborne dust from cutoff and grinding operations is also collected in a baghouse system. It is high in metal content and is sent to the furnaces for remelting.

\subsection{AIRBORNE DUST FROM MOLDING OPERATIONS}

Dust from sand molding operations contains metals, and thus can be hazardous. Airborne dust is collected by a hydrofilter that consists of a wet scrubber and a cyclone separator. In the settling tank, the dust, now "mud," sinks to the bottom and is carried out on a conveyor system. It is reused for making molds.

\subsection{FEED MATERIALS}

Input metals for making the brass are themselves generated in recycling operations. Eighty per cent of the new feed metals are taken from used automobile radiators. Feed materials are carefully monitored to keep process efficiency high and reject rates low. The plant is especially careful about preventing any aluminum from getting into the process streams. A $0.001 \%$ aluminum content will "poison" the brass, causing leaks in the plumbing fixtures manufactured from it. For this reason, soda cans are strictly prohibited in the foundry area.

In studies done by Plant $X$, it was shown that internal recycling measures such as the ones described above typically offer three times the financial benefits compared to 
sending metals to an offsite reclaimer. This is another illustration that implementing pollution prevention results in increased profits for the company or institution.

Plant $X$ provides an especially good example of pollution prevention because it has implemented a comprehensive program that examines rearly every waste stream, finding ways to eliminate it or turn it into something beneficial for the company.

\section{Summary}

While pollution prevention can use many widely varying methodologies, the goal is always the same: to reduce or eliminate the creation of waste within the processes that generate it. There is a direct correlation between reducing waste and increasing a company's profits. Reducing waste generation and making an industrial process more efficient go hand in hand. As illustrated in the case of Plater B, a redesigned process can be both more productive and less polluting. As shown in the examples of Plater A and Plant $X$, considering waste streams to be unused resources and finding applications for them, preferably within the plant itself, creates a win-win situation that cuts waste management expenses and benefits the environment. 
Table 1:

\section{SOURCE REDUCTION THROUGH PROCESS CHANGES}

The following process changes are pollution prevention measures because they reduce the amount of waste created during production:

\begin{tabular}{|c|c|}
\hline $\begin{array}{l}\text { Examples of input } \\
\text { material changes: }\end{array}$ & $\begin{array}{l}\text { - Stop using heavy metal pigment. } \\
\text { - Use a less hazardous or toxic solvent for cleaning or as } \\
\text { coating. } \\
\text { - Purchase raw materials that are free of trace quantities of } \\
\text { hazardous or toxic materials. }\end{array}$ \\
\hline $\begin{array}{l}\text { Examples of technology } \\
\text { changes: }\end{array}$ & $\begin{array}{l}\text { - Redesign equipment and piping to reduce the volume of } \\
\text { material they contain. Cut losses during batch or color } \\
\text { changes or when equipment is drained for maintenance or } \\
\text { cleaning. } \\
\text { - Change to mechanical stripping/cleaning devices to avoid } \\
\text { solvent use. } \\
\text { - Change to a powder-coating system. } \\
\text { - Install a hard-piped vapor recovery system to capture and } \\
\text { retum vaporous emissions. } \\
\text { - Use more efficient motors. } \\
\text { - Install speed control on pump motors to reduce energy } \\
\text { consumption. }\end{array}$ \\
\hline $\begin{array}{l}\text { Examples of improved } \\
\text { operating practices: }\end{array}$ & $\begin{array}{l}\text { - Train operators. } \\
\text { - Cover solvent tanks when not in use. } \\
\text { - Segregate waste streams to avoid cross-contaminating } \\
\text { hazardous and nonhazardous materials. } \\
\text { - Improve control of operating conditions (e.g., flow rate, } \\
\text { temperature, pressure, residence time, stoichiometry). } \\
\text { - Improve maintenance scheduling, record keeping, or } \\
\text { procedures to increase efficiency. } \\
\text { - Optimize purchasing and inventory maintenance methods } \\
\text { for input materials. Purchasing in quantity can reduce } \\
\text { costs and packaging material if care is taken to ensure that } \\
\text { materials do not exceed their shelf lives. Reevaluate shelf } \\
\text { life characteristics to avoid unnecessary disposal of stable } \\
\text { items. } \\
\text { - Stop leaks, drips, and spills. } \\
\text { - Turn off electrical equipment such as lights and copiers } \\
\text { when not in use. } \\
\text { - Place equipment so as to minimize spills and losses } \\
\text { during transport of parts or materials. } \\
\text { - Use drip pans and splash guards. }\end{array}$ \\
\hline
\end{tabular}


Table 2.

COMPARISON OF HEXAVALENT AND TRIVALENT SYSTEM COSTS

HEX

TRI

\begin{tabular}{|c|c|c|c|c|c|c|}
\hline & $\begin{array}{l}\text { Unit } \\
\text { Cost } \\
\end{array}$ & $\begin{array}{c}\text { Qty Used } \\
\text { Per } \\
\text { Shift (1) } \\
\end{array}$ & $\begin{array}{l}\text { Cost } \\
\text { Per } \\
\text { Shift } \\
\end{array}$ & $\begin{array}{l}\text { Unit } \\
\text { Cost } \\
\end{array}$ & \begin{tabular}{|c|} 
Qty Used \\
Per \\
Shift (1) \\
\end{tabular} & $\begin{array}{l}\text { Cost } \\
\text { Per } \\
\text { Shint } \\
\end{array}$ \\
\hline \multicolumn{7}{|l|}{ PLATING CHEMICALS } \\
\hline Chromic acid & $\$ 1.08 / \mathrm{lb}$ & 28.8 & $\$ 31.10$ & & & \\
\hline Chrome catalyst & $15.00 / 1 \mathrm{~b}$. & $0.3 / \mathrm{b}$ & 4.32 & & & \\
\hline Trichrome additive \#1 & & & & $\$ 28.75 / \mathrm{gal}$ & $1.9 \mathrm{gal}$. & 54.63 \\
\hline Trichrome additive \#2 & & & & $28.25 / \mathrm{gal}$. & $1.5 \mathrm{gal}$. & 42.38 \\
\hline Trichrome base salts & & & & $1.97 / \mathrm{b}$. & $18 \mathrm{lbs}$. & 35.68 \\
\hline Boric acid & & & & $0.36 / 1 \mathrm{~b}$ & 19 lbs. & 3.60 \\
\hline Trichrome Wetter & & & & $12.75 / \mathrm{gal}$. & $0.6 \mathrm{gal}$. & 7.65 \\
\hline Hydrogen peroxide & & & & $8.00 / \mathrm{gal}$ & $0.5 \mathrm{gal}$. & 4.00 \\
\hline \multicolumn{7}{|l|}{ TREATMENT CHEMICALS } \\
\hline Sodium Metabisulfite & $0.33 / \mathrm{b}$ & 86.4 lbs. & 28.51 & & & \\
\hline Lime & $0.9 / 1 \mathrm{~b}$ & $28.8 \mathrm{lbs}$. & 2.71 & & & \\
\hline \multicolumn{7}{|l|}{$\begin{array}{l}\text { LIIIE } \\
\text { ENERGY USAGE }\end{array}$} \\
\hline Electrical & $\$ 0.085 / \mathrm{kwh}$ & $196 \mathrm{kwh}$ & 16.66 & $\$ 0.085 / \mathrm{kwh}$ & $115 \mathrm{kwh}$ & 9.69 \\
\hline Natural Gas & \$0.65/therm & 6.9 therm & 4.47 & $\$ 0.65 /$ therm & 9.6 therm & 6.24 \\
\hline \multicolumn{7}{|l|}{ OPERATING VARIABLES } \\
\hline Rejects & & $1.5 \%$ & $81.00(2)$ & & $0.5 \%$ & $27.00(2)$ \\
\hline Operating Costs & & & 168.77 & & & 190.87 \\
\hline $\begin{array}{c}\text { Gross Profit per Shift } \\
\text { (Calculated at } \$ 0.20 \text { per } \\
\text { square foot of parts plated) } \\
\end{array}$ & 0.20 & $7200 \mathrm{ft}^{2}(3)$ & 1440.00 & 0.20 & $8220 \mathrm{ft}^{2}(3)$ & 1644.00 \\
\hline $\begin{array}{l}\text { NET PROFIT per shift } \\
\text { (Gross profit - Op. Cost) }\end{array}$ & & & $\underline{1271.23}$ & & & $145 \dot{3} .13$ \\
\hline $\begin{array}{l}\text { Additional Profits in } \\
\text { Trivalent System }\end{array}$ & & & & & & 181.90 \\
\hline
\end{tabular}

1. Shifts are 8 hours in length.

2. Cost for rerunning rejected parts.

3. Trivalent process is able to plate $15 \%$ more parts per shift, due to higher parts densities on racks. 
Table 3.

COMPARISON OF PLATING BATH OPERATING CHARACTERISTICS

\begin{tabular}{|l|c|c|}
\hline & HEX & TRI \\
\hline Temperature & $110^{\circ} \mathrm{F}$ & $120^{\circ} \mathrm{F}$ \\
Parts area per rack & $12 \mathrm{ft}^{2}$ & $13.8 \mathrm{ft}^{2}$ \\
Plating time per part & $20 \mathrm{sec}$ & $100 \mathrm{sec}$ \\
Current density & $200 \mathrm{amp} / \mathrm{ft}^{2}$ & $68 \mathrm{amp} / \mathrm{ft}^{2}$ \\
Amperage for entire tank & $2400 \mathrm{amp}$ & $2100 \mathrm{amp}$ \\
Tank voltage & $12 \mathrm{volt}$ & $8 \mathrm{volt}$ \\
KWH/shift, @ 85\% rectifier efficiency & $196 \mathrm{KWH}$ & $114 \mathrm{KWH}$ \\
\hline
\end{tabular}




\section{References}

DHS. September 1989. Reducing California's Metal-Bearing Wastes. California Department of Health Services, Toxic Substances Control Division, Alternative Technology Section. Prepared by Jacobs Engineering Group, Inc. Pasadena. California.

DHS. December 1990. Waste Audit Study: Thermal Metal Working Industry. California Department of Health Services, Toxic Substances Control Program, Alternative Technology Division. Prepared by Jacobs Engineering Group, Inc. Pasadena. California.

Durney, L.J. April 1986. "Pioneer Really Pioneers." Products Finishing. Gardner Publications, Inc. Cincinnati, Ohio

EPA 1992. Facility Pollution Prevention Guide. Office of Solid Waste, U.S. Environmental Protection Agency. Washington D.C.

Foss, L. 1989. “Closed Loop Plating System for Waste Minimization.” Metal Waste Management Alternatives. California Department of Health Services, Toxic Substances Control Division, Alternative Technology Section. Prepared by Foss Plating Company.

Gumm, February 1989. Envirochrome Decorative Trivalent Chromium Plating Process. Technical Bulletin of Frederick Gumm Chemical Company, Inc. Kearny, New Jersey.

Robison, G.T. August 1978. "Wire Goods Manufacturer Plates Trivalent Chromium." Products Finishing. Gardner Publications, Inc. Cincinnati, Ohio.

Smart, D., Such, T.E., and Wake, S.J. 1983. "A Novel Trivalent Chromium Electroplating Bath." Bulletin of the Institute of metal Finishing. Vol. 61, pp. 105110.

Snyder, D.L. August 1989. "The Case for Trivalent Chromium." Products Finishing. Gardner Publications, Inc. Cincinnati, Ohio.

*This work was performed under the auspices of the U.S. Department of Energy by Lawrence Livermore National Laboratory under contract No. W-7405-Eng-48. 

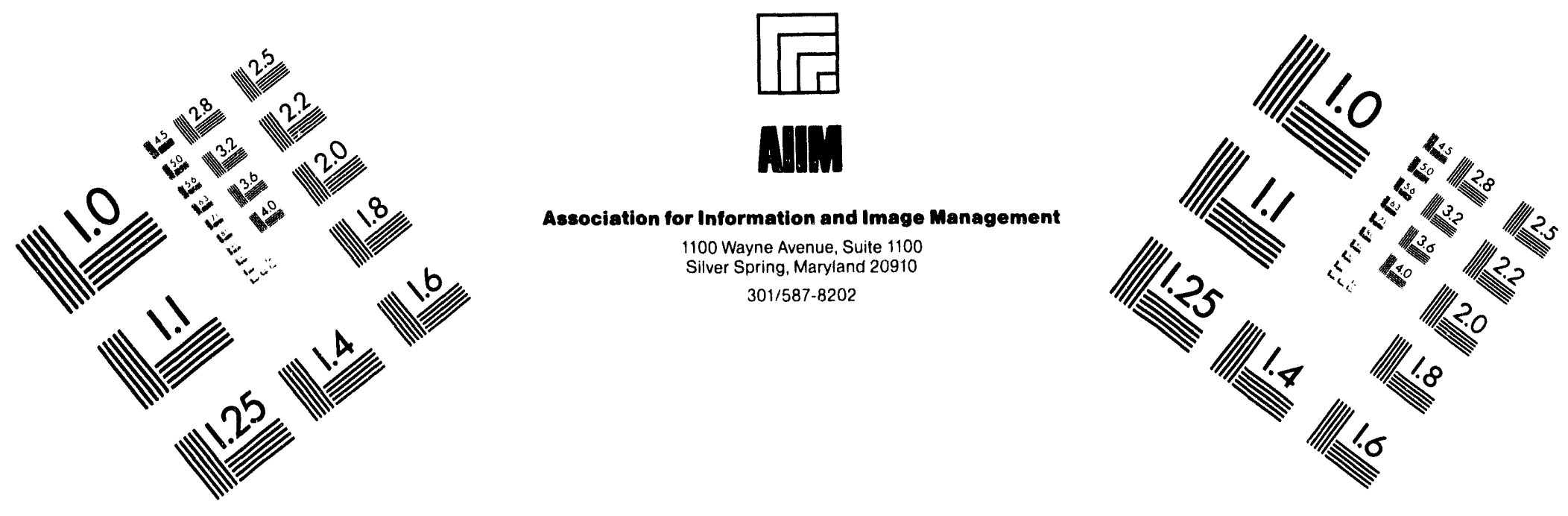

\section{Centimeter}

${ }_{1}$

Inches
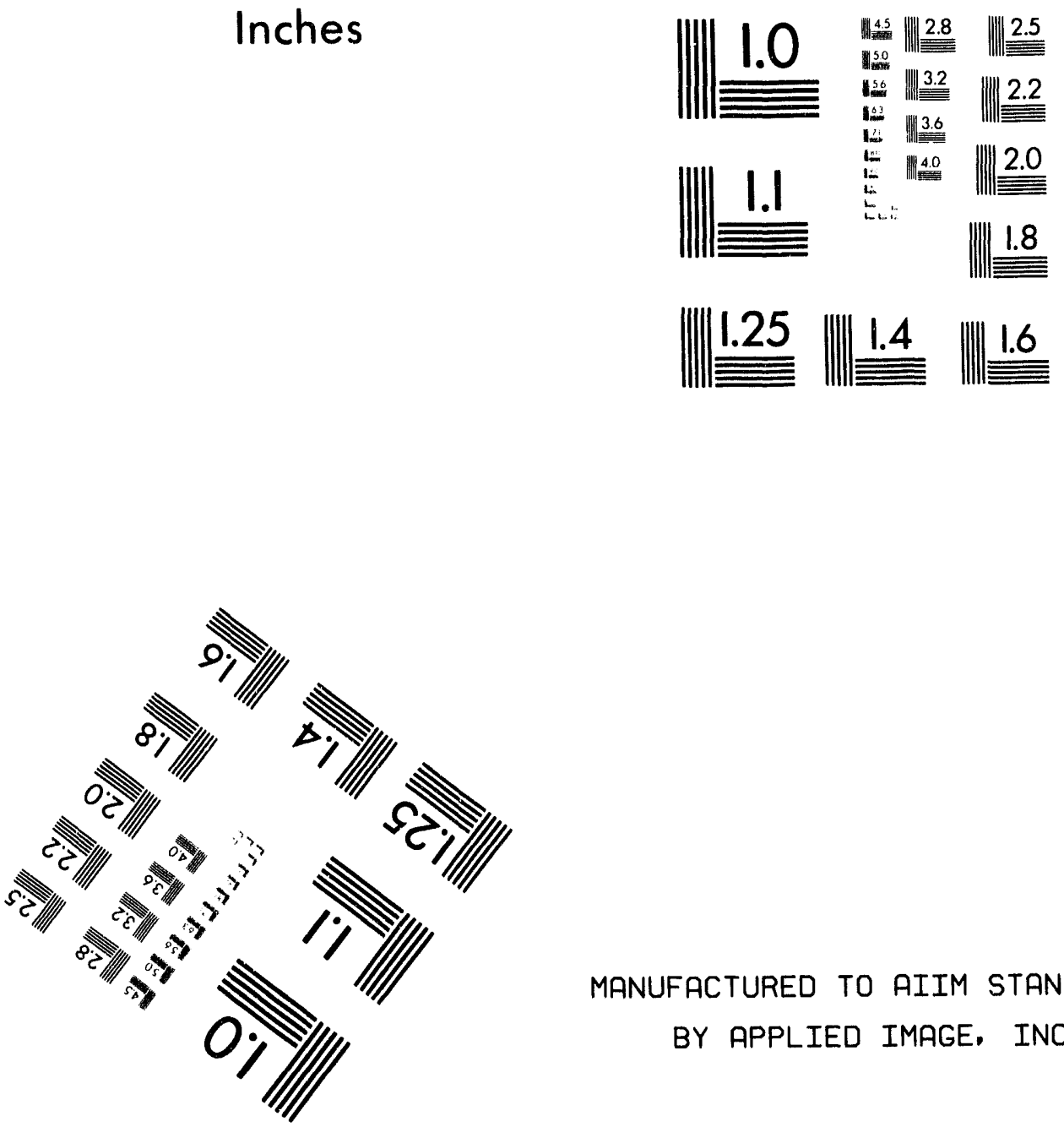

MANUFACTURED TO AIIM STANDARDS

BY APPLIED IMAGE, INC.






